\title{
Pemanfaatan Batu Kapur Madura sebagai Katalis dalam Pembuatan Bioedesel dari Minyak Nyamplung
} \author{
Esti Purbaningtias ${ }^{\mathrm{c}}$, Zeni Rahmawati ${ }^{\mathrm{d}}$, Septian Dwi Wijaya ${ }^{\mathrm{a}}$ \\ a Jurusan Teknik Mesin Alat Berat, Politeknik Negeri Madura, Indonesia \\ b Jurusan Teknik Bangunan Kapal, Politeknik Negeri Madura, Indonesia \\ c Jurusan Kimia, Prodi Analisis Kimia, Universitas Islam Indonesia, Yogyakarta, Indonesia \\ d Jurusan Kimia, Institut Teknologi Sepuluh Nopember, Surabaya, Indonesia \\ *corresponding author: ahamchimie@poltera.ac.id \\ DOI : 10.20885/ijca.vol5.iss1 .art2
}

Ike Dayi Febriana ${ }^{\mathrm{a}}$, Abdul Hamid ${ }^{\mathrm{a}, *}$, Amin Jakfar ${ }^{\mathrm{a}}$, Mohammad Abdullah ${ }^{\mathrm{b}}$, Faizatur Rohmah ${ }^{\mathrm{a}}$, Tri

\begin{tabular}{l} 
ARTIKEL INFO \\
\hline Diterima $\quad: 23$ Oktober 2021 \\
Direvisi $\quad: 18$ November 2021 \\
Diterbitkan $: 01$ Maret 2022 \\
Kata Kunci : Biodiesel, Batu Kapur, \\
Minyak Nyamplung, Transesterifikasi
\end{tabular}

ARTICLE INFO

Received : 23 October 2021

Revised : 18 November 2021

Published : 01 March 2022

Keywords : Biodiesel, Limestone,

Nyamplung Oil, Transesterification

\begin{abstract}
ABSTRAK
Pemanfaatan batu kapur dari Pamekasan, Madura sebagai katalis heterogen pada reaksi pembuatan biodiesel dipelajari pada penelitian ini. Batu kapur dikalsinasi pada suhu $900{ }^{\circ} \mathrm{C}$ selama 3 jam untuk membentuk katalis $\mathrm{CaO}$. Katalis $\mathrm{CaO}$ yang terbentuk dikarakterisasi menggunakan difraksi sinar-X (XRD), spektroskopi inframerah (FTIR) dan Scanning Electron Microscopy-Energy Dispersive X-Ray Analysis (SEM-EDX). Produk biodiesel yang terbentuk dianalisis menggunakan Gas Chromatography-Mass Spectroscopy (GC-MS). Hasil karakterisasi XRD menunjukkan puncak karakteristik $\mathrm{CaO}$ pada $2 \theta=36,95^{\circ} ; 54,38^{\circ} ; 64,28^{\circ}$ dan $78,61^{\circ}$. Analisis FTIR menunjukkan bahwa $\mathrm{CaO}$ yang disintesis dari batu kapur belum memperoleh senyawa $\mathrm{CaO}$ murni. Hasil karakterisasi menggunakan SEM-EDX menunjukkan bahwa morfologi padatan menyerupai balok dan prisma serta diperoleh ukuran partikel sekitar $10 \mu \mathrm{m}$. Proses transesterifikasi dari minyak nyamplung dilakukan dengan rasio mol minyak terhadap methanol sebesar $1: 16$ pada temperatur $60{ }^{\circ} \mathrm{C}$ selama 1 jam dengan katalis $\mathrm{CaO}$ sebesar $4 \%(\mathrm{w} / \mathrm{w})$. Hasil analisis GC-MS diperoleh yield biodiesel sebesar 54\% dengan konversi sebesar $49 \%$.
\end{abstract}

\section{ABTRACT}

Utilization of limestone from Pamekasan, Madura as heterogeneous catalyst in the biodiesel production reaction has been studied. Limestone was calcined at 900 C for 3 hours to form $\mathrm{CaO}$ catalyst. The $\mathrm{CaO}$ catalyst formed was characterized using $X$ ray diffraction (XRD), infrared spectroscopy (FTIR) and Scanning Electron Microscopy-Energy Dispersive X-Ray Analysis (SEM$E D X)$. The biodiesel product formed was analyzed using Gas Chromatography-Mass Spectroscopy (GC-MS). The result of XRD characterization shows the characteristic peak of $\mathrm{CaO}$ at $2 \theta=$ $36.95^{\circ} ; 54.38^{\circ} ; 64.28^{\circ}$ and $78.61^{\circ}$. FTIR analysis showed that $\mathrm{CaO}$ synthesized from limestone had not obtained pure CaO compounds. The results of characterization using SEM-EDX showed that the morphology of the solids resembled formed beams and prisms, and it obtained particle size around $10 \mu \mathrm{m}$. The transesterification process of nyamplung oil was carried out with mole ratio of oil to 
methanol of $1: 16$ at $60{ }^{\circ} \mathrm{C}$ for 1 hour with CaO catalyst of $4 \%$ $(w / w)$. The results of GC-MS analysis was obtained biodiesel yield of $54 \%$ with conversion at $49 \%$.

\section{PENDAHULUAN}

Kemajuan teknologi dan industri berdampak pada peningkatan konsumsi energi, khususnya bahan bakar fosil. Padahal, bahan bakar fosil merupakan energi tak terbarukan yang jumlahnya semakin terbatas, sehingga energi ramah lingkungan dan terbarukan seperti biodiesel sangat dibutuhkan untuk menggantikan bahan bakar fosil [1]. Biodiesel merupakan salah satu produk hasil reaksi transesterifikasi antara minyak nabati/lemak hewani (trigliserida) dan mono-alkohol dengan adanya katalis, juga dikenal sebagai fatty acid methyl esters, adalah bahan bakar lebih bersih yang ramah lingkungan dan dapat memainkan peran penting dalam energi terbarukan [2]. Secara kimiawi, alkil metil ester dengan rantai panjang asam lemak dapat diproduksi melalui esterifikasi asam lemak atau transesterifikasi minyak nabati, lemak hewani dan minyak goreng. Reaksi terjadi karena adanya alkohol dengan rantai pendek dan katalis homogen atau heterogen yang sesuai [3]. Meningkatnya permintaan energi global akibat pertumbuhan penduduk dunia dan industrialisasi serta menipisnya bahan bakar fosil telah mendorong penelitian terhadap produksi sumber energi terbarukan dan berkelanjutan. Minyak alam yang berasal dari tanaman pertanian seperti kelapa sawit, ubi kayu, jagung dan kelapa diteliti sebagai sumber produksi biofuel. Namun, memanen tanaman pertanian yang dapat dimakan untuk produksi biofuel menyebabkan masalah etika dan oleh karena itu pemanfaatan tanaman yang tidak dapat dimakan menjadi jalur yang layak untuk mempertahankan produksi biodiesel. Minyak alami yang diekstrak dari tanaman yang tidak dapat dimakan seperti biji kapas (Gossypium arboretum L.) biji jarak (Jatropha curcas L), biji palem (Areca catechu L.) dan biji nyamplung (Calophyllum inophyllum) telah diteliti sebagai sumber potensial untuk produksi biodiesel [4].

Penggunaan katalis dalam produksi biodiesel diperlukan untuk meningkatkan laju reaksi dan meningkatkan yield biodiesel yang dihasilkan. Katalis heterogen terus dipelajari oleh peneliti dalam upaya untuk membangun proses yang lebih berkelanjutan. Kalsium oksida $(\mathrm{CaO})$ adalah salah satu katalis heterogen yang paling banyak dipelajari karena aktivitasnya yang sangat baik dalam reaksi transesterifikasi, ketersediaan dan biaya rendah, dan dapat diperoleh dari mineral alam [5]. Oksida logam seperti $\mathrm{CaO}$ telah diteliti sebagai katalis padat. Katalis padat ini tidak dikonsumsi atau larut dalam reaksi, oleh karena itu dapat dengan mudah dipisahkan dari produk [6]. Sebagai hasilnya, produk tidak mengandung pengotor dari katalis dan biaya pemisahan akhir dapat dikurangi. Katalis ini juga bisa diregenerasi dan digunakan kembali serta lebih ramah lingkungan karena tidak dibutuhkan perlakuan asam atau air pada tahap pemisahannya [7]. Selain itu katalis oksida logam seperti $\mathrm{CaO}$ terdiri atas kation yang mempunyai sisi asam Lewis dan anion yang mempunyai sisi basa Bronsted. Diantara oksida-oksida logam dari alkali tanah, kalsium oksida telah menarik banyak perhatian untuk reaksi transesterifikasi karena mempunyai beberapa kelebihan seperti kebasaan yang tinggi, lebih ramah lingkungan karena kelarutan yang rendah dalam metanol, dan dapat disintesis dari bahan-bahan yang murah seperti batu kapur dan kalsium hidroksida [8]. Selain itu, penggunaan katalis $\mathrm{CaO}$ pada beberapa minyak tumbuhan menghasilkan biodiesel dengan yield yang tinggi, yaitu $>89 \%$ pada minyak microalgal atau chlorella vulgaris [9], 97,96\% pada minyak tumbuhan Hydnocarpus Wightiana [10], >90\% pada minyak kedelai [11] dan >90\% pada minyak jarak [12].

Oleh karena itu, pada penelitian ini akan dilakukan pembuatan biodiesel dari minyak nyamplung menggunakan katalis $\mathrm{CaO}$ dari batu kapur yang berasal dari Pamekasan, Madura. Aktivitas katalis $\mathrm{CaO}$ dari batu kapur madura diteliti sebagai katalisator untuk reaksi transesterifikasi minyak nyamplung (Calophyllum inophyllum) yang berasal dari biji nyamplung. Padatan katalis $\mathrm{CaO}$ yang terbentuk dikarakterisasi menggunakan teknik XRD, FTIR dan SEMEDX. Sedangkan untuk mengetahui produk biodiesel yang terbentuk dianalisis menggunakan GCMS. 


\section{METODE}

\subsection{Alat dan Bahan}

Peralatan yang digunakan dalam penelitian ini antara lain peralatan-peralatan gelas, hotplate magnetic stirrer, stirer (pengaduk magnetik), oven, neraca analitik, termometer, kondensor refluks, instrumen X-Ray Diffraction Phillips Expert, FTIR Shimadzu Instrument Spectrum One 8400S, Scanning Electron Microscopy (SEM) (Zeizz Evo MA10) dan Gas Chromatography-Mass Spectrometry (GC-MS) (Teknologi Agilent 6820).

Bahan-bahan yang diperlukan dalam penelitian ini adalah akuades, minyak nyamplung (Calophyllum inophyllum) sebagai sumber minyak, batu kapur dari Pamekasan, Madura sebagai katalis $\mathrm{CaO}$, metanol (Merck, 99\%), $\mathrm{H}_{2} \mathrm{SO}_{4}$, n-Heksan dan $\mathrm{HCl}$ (Smart-Lab).

\subsection{Pembuatan katalis $\mathrm{CaO}$ dari batu kapur}

Batu kapur terlebih dahulu dihancurkan hinggga menjadi serbuk. Kemudian di ayak menggunakan ayakan 125 mesh. Kemudian di keringkan dalam oven pada suhu $110^{\circ} \mathrm{C}$ selama 2 jam. Sampel batu kapur yang sudah kering kemudian di furnace pada suhu $900{ }^{\circ} \mathrm{C}$ selama 3 jam agar terbentuk padatan $\mathrm{CaO}$.

\subsection{Karakterisasi katalis $\mathrm{CaO}$ dari batu kapur}

Padatan hasil sintesis dikarakterisasi dengan difraksi sinar-X, FTIR dan SEM-EDX. Pengukuran XRD dilakukan dengan radiasi $\mathrm{Cu} \mathrm{K} \alpha$ pada difraktometer XRD merek Bruker D2 Phaser pada kisaran $5^{\circ}-80^{\circ}(2 \theta), \lambda=1,54056 \AA$ untuk identifikasi fase. Spektrum inframerah (Nicolet Avatar 360 IR) dilakukan menggunakan pelet $\mathrm{KBr}$ pada bilangan gelombang antara 1400 dan $400 \mathrm{~cm}^{-1}$. Padatan yang dihasilkan dikarakterisasi dengan SEM-EDX (Phenom Desktop ProXL). Sampel dicoating dengan $\mathrm{Pd} / \mathrm{Au}$ selama 15 detik pada tekanan $6 \times 10^{-2}$ mbar kemudian diletakkan pada alas carbon tape. Selanjutnya sampel dianalisa menggunakan SEM dan EDX.

\subsection{Preparasi minyak nyamplung}

Proses esterifikasi dari minyak nyamplung dilakukan dengan rasio mol minyak terhadap methanol sebesar 1:16. Minyak nyamplung dimasukkan ke dalam labu bundar yang dilengkapi dengan pengaduk magnet dan refluks kondensor untuk menghindari penguapan methanol. Kemudian ditambahkan $\mathrm{H}_{2} \mathrm{SO}_{4}$ sebanyak $1 \%(\mathrm{w} / \mathrm{w})$ dari berat minyak. Labu bundar diletakkan di atas hotplate magnetic stirrer dengan suhu $60^{\circ} \mathrm{C}$ selama 1 jam dengan kecepatan pengadukan 800 $\mathrm{rpm}$. Hasil reaksi terdiri atas dua lapisan yang kemudian dipisahkan dengan corong pisah. Minyak pada lapisan bawah di ambil dan selanjutnya digunakan untuk reaksi transesterifikasi.

\subsection{Reaksi transesterifikasi}

Transesterifikasi minyak nyamplung menjadi biodiesel dilakukan pada labu bundar yang dilengkapi dengan magnetic stirer dan termometer. Reaksi transesterifikasi dimulai dengan mereaksikan minyak nyamplung hasil esterifikasi dengan metanol menggunakan katalis $\mathrm{CaO}$ dari batu kapur sebesar $4 \%(w / w)$ terhadap berat minyak. Reaksi transeterifikasi dilakukan dalam labu bundar dengan rasio mol minyak terhadap methanol sebesar 1:16 yang dilengkapi refluks kondensor untuk menghindari penguapan metanol. Reaksi transesterifikasi dilakukan pada suhu 60 ${ }^{\circ} \mathrm{C}$ selama 1 jam dengan kecepatan pengadukan $1000 \mathrm{rpm}$. Minyak biodiesel yang terbentuk dianalisis menggunakan GC-MS untuk mengetahui kandungan metil esternya. Analisis kuantitatif konversi minyak dan yield biodiesel dihitung menggunakan persamaan 1 dan 2 [13].

$$
\text { Konversi }=\frac{W a-W b}{W a} 100 \%
$$

Dimana: Wa: massa minyak awal (gram), Wb: massa biodiesel yang terbentuk (gram).

$$
\text { Yield biodiesel }=\left(\frac{\Sigma A M E}{A \text { is }}\right)\left(\frac{C \text { is } x \text { V is }}{M \text { sampel }}\right) 100 \%
$$


Dimana: $\Sigma$ A ME merupakan jumlah area semua puncak metil ester, $A_{\text {is }}$ : luas puncak internal standard, $\mathrm{C}_{\text {is }}$ : konsentrasi internal standard (ppm), $\mathrm{V}_{\text {is }}$ : volume internal standard ( $\mathrm{ml}$ ) dan $\mathrm{M}_{\text {sampel }}$ merupakan berat sampel $(\mathrm{mg})$.

\section{HASIL PENELITIAN}

Karakterisasi menggunakan XRD (X-Ray Diffraction) digunakan untuk mengidentifikasi fase kristal, struktur kristal dan kristalinitas dari suatu sampel [14]. Sampel yang dikarakterisasi menggggunakan XRD adalah sampel batu kapur sebelum dan sesudah kalsinasi. Sampel dianalisis menggunakan sudut (20) antara $10^{\circ}-80^{\circ}$. Sampel batu kapur dikasinasi pada suhu $900{ }^{\circ} \mathrm{C}$ selama 3 jam untuk melihat perubahan dari $\mathrm{CaCO}_{3}$ menjadi katalis $\mathrm{CaO}$. Hasil karakterisasi XRD dari sampel batu kapur ditunjukkan pada Gambar 1. Perubahan pola difraksi sinar-X dari sampel sebelum dan sesudah kalsinasi terlihat pada gambar tersebut. Puncak difraktogram dari sampel sebelum kalsinasi menunjukkan puncak-puncak utama seperti $\mathrm{CaMg}\left(\mathrm{CO}_{3}\right)_{2}$ (dolomit). Setelah kalsinasi puncak tersebut kemudian menghilang dan terlihat puncak-puncak baru seperti puncak $\mathrm{CaO}$. Hal ini mengindikasikan bahwa batu kapur bertransformasi dari $\mathrm{CaCO}_{3}$ menjadi $\mathrm{CaO}$ dengan adanya pemanasan pada suhu tinggi.

$\mathrm{CaO}$ dari kalsium karbonat diperoleh melalui proses kalsinasi batu kapur. Kalsium karbonat $\left(\mathrm{CaCO}_{3}\right)$ dapat diperoleh dari batuan sedimen seperti batu kapur yang mengandung senyawa $\mathrm{CaCO}_{3}$ dari proses kalsinasi untuk mendekomposisi kalsium karbonat menjadi kalsium oksida $(\mathrm{CaO})$ dan gas karbondioksida atau $\mathrm{CO}_{2}$ [15]. Difraktogram Sampel batu kapur sebelum kalsinasi menunjukkan puncak-puncak pada $2 \theta=24,15^{\circ} ; 31,03^{\circ} ; 37,45^{\circ} ; 41,21^{\circ} ; 45,02^{\circ}$ dan $51,47^{\circ}$. Puncak-puncak tersebut menunjukkan adanya fase $\mathrm{CaMg}\left(\mathrm{CO}_{3}\right)_{2}$. Sedangan untuk sampel batu kapur setelah kalsinasi menunjukkan puncak-puncak baru yaitu pada $2 \theta=18,01^{\circ} ; 34,01^{\circ}$ dan $50,81^{\circ}$ merupakan fase $\mathrm{Ca}(\mathrm{OH})_{2}$, pada $2 \theta=28,68^{\circ}$ dan $47,13^{\circ}$ merupakan fase $\mathrm{CaCO}_{3}$ dan pada $2 \theta$ $=42,93^{\circ}$ dan $62,29^{\circ}$ merupakan fase $\mathrm{MgO}$. Untuk puncak karakteristik dari $\mathrm{CaO}$ sendiri terlihat pada $2 \theta=36,95^{\circ} ; 54,38^{\circ} ; 64,28^{\circ}$ dan $78,61^{\circ}[16]$.

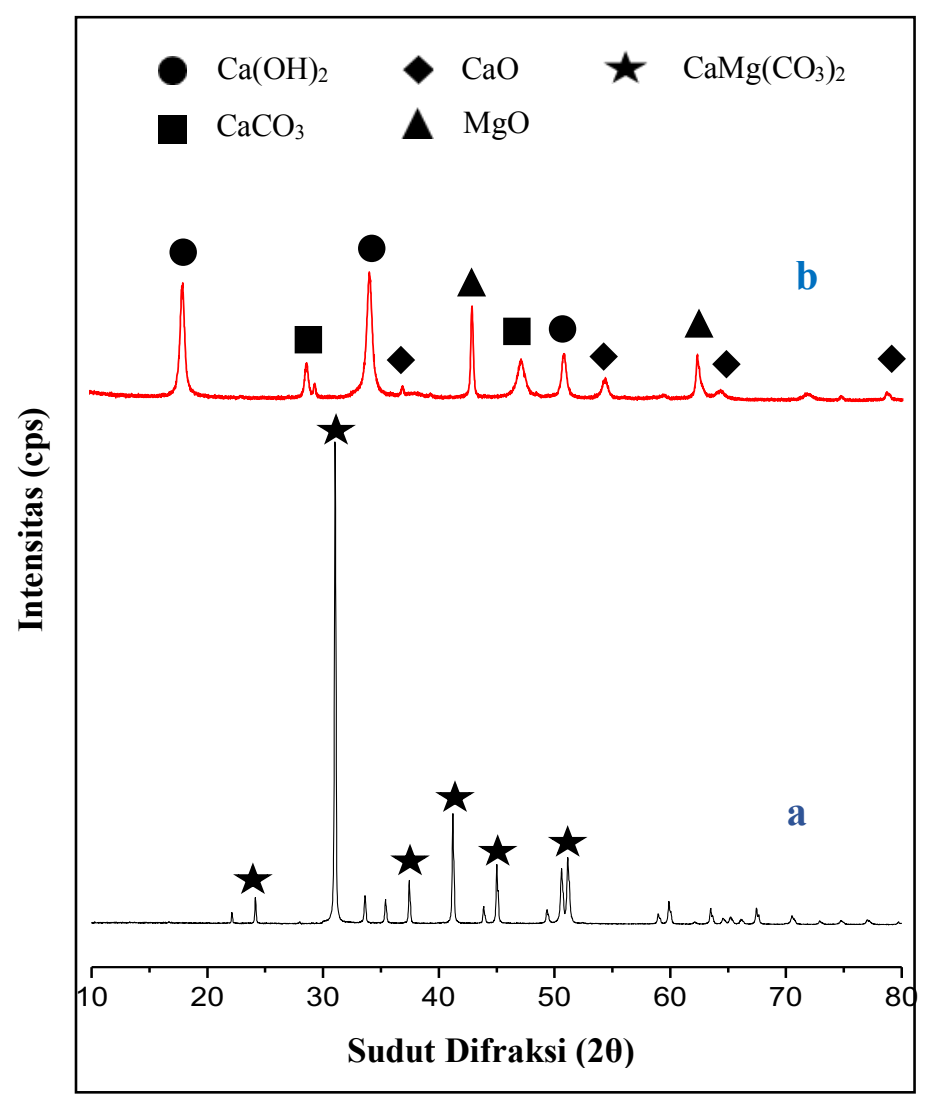

Gambar 1. Difraktogram sampel batu kapur sebelum kalsinasi (a) dan sesudah kalsinasi (b) 


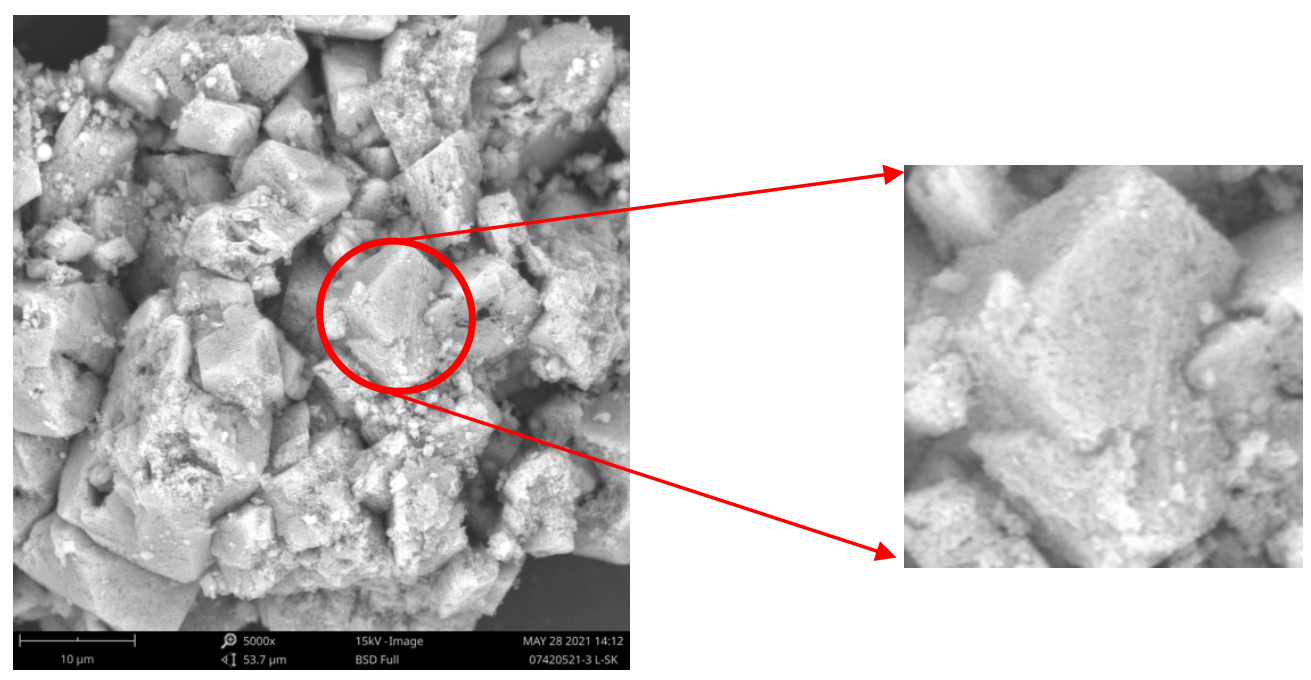

Gambar 2. Morfologi dari sampel batu kapur setelah kalsinasi
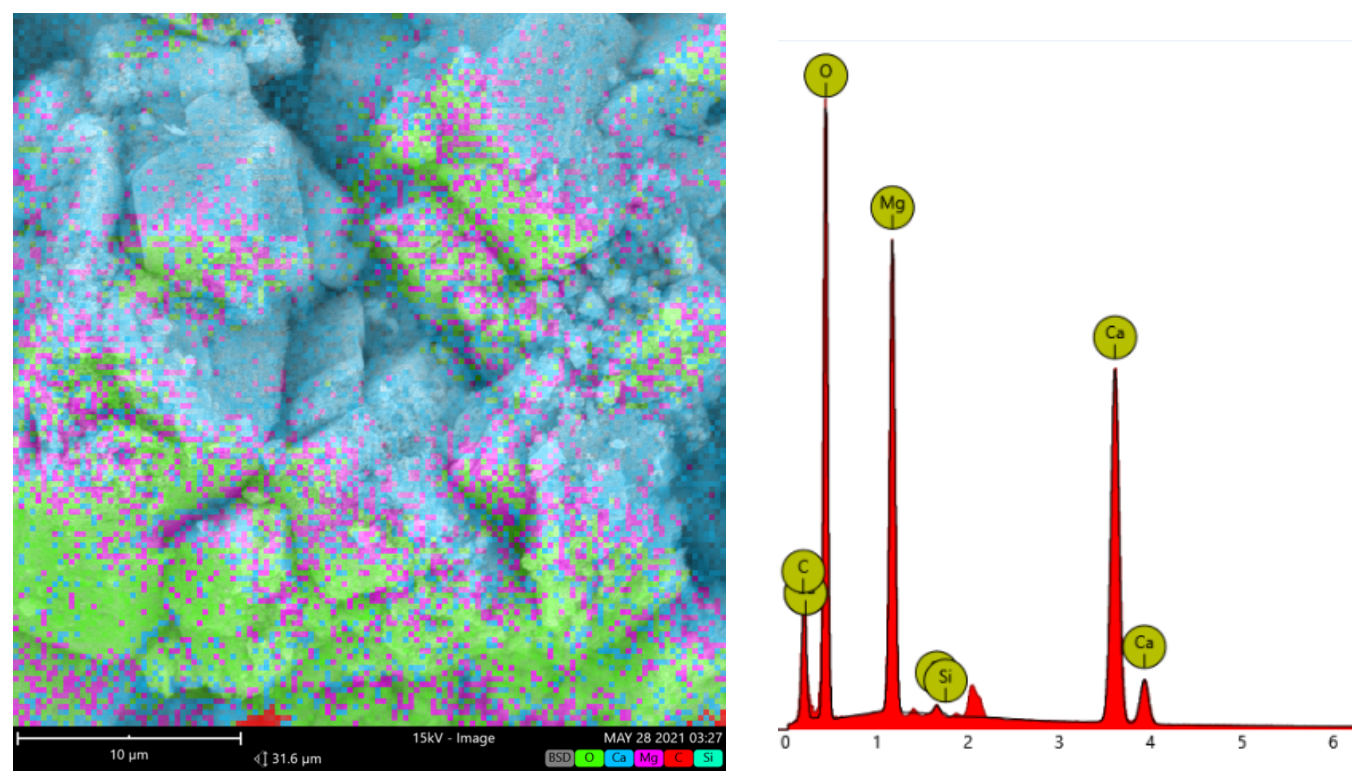

Gambar 3. Mapping unsur dan spektrum EDX dari sampel batu kapur setelah kalsinasi

Hasil karakterisasi menggunakan SEM-EDX untuk sampel batu kapur setelah kalsinasi ditunjukkan pada Gambar 2 dan 3. Karakterisasi menggunakan SEM digunakan untuk mengetahui morfologi permukaan dari sampel padatan. Morfologi dan ukuran partikel dari sampel diamati dengan Scanning Electron Microscopy (SEM), sedangkan untuk mengetahui kandungan unsurunsur yang terdapat pada sampel digunakan Energy Dispersive X-ray (EDX). Pada Gambar 5 menunjukkan morfologi yang tidak teratur dari sampel batu kapur setelah kalsinasi. Terdapat beberapa padatan yang menyerupai balok dan prisma. Berdasarkan analisis mengunakan SEM diperoleh ukuran partikel sekitar $10 \mu \mathrm{m}$. Hasil spektrum EDX ditunjukkan pada gambar 5. Gambar tersebut menunjukkan bahwa sampel terdiri dari unsur-unsur $\mathrm{Ca}, \mathrm{Si}, \mathrm{Mg}, \mathrm{C}$ dan $\mathrm{O}$. Unsur oksigen, kalsium dan magnesium merupakan kandungan utama dari material batu kapur. Komposisi unsurunsur penyusun sampel batu kapur juga bisa dilihat dari hasil mapping dari instrumen SEM. Gambar tersebut menunjukkan persebaran masing-masing unsur penyusun batu kapur. Komposisi unsur-unsur yang terdapat pada sampel batu kapur ditunjukkan pada Tabel 1. Kandungan unsur tertinggi dalam sampel batu kapur yaitu kalsium diperoleh sekitar 36,84\%. 
TABEL I. Komposisi unsur-unsur dalam sampel batu kapur

\begin{tabular}{cc}
\hline Unsur & Kadar unsur (\% berat) \\
\hline $\mathbf{O}$ & 32,93 \\
\hline $\mathbf{C a}$ & 36,84 \\
\hline $\mathbf{M g}$ & 19,03 \\
\hline $\mathbf{S i}$ & 0,19 \\
\hline $\mathbf{C}$ & 11,01 \\
\hline
\end{tabular}

Hasil karakterisasi FTIR dari sampel batu kapur sebelum dan sesudah kalsinasi ditunjukkan pada Gambar 4 . Dari kedua gambar tersebut menunjukkan regangan $\mathrm{OH}$ dari air dan $\mathrm{Ca}(\mathrm{OH})_{2}$ pada puncak yang melebar di sekitar 3400-3500 $\mathrm{cm}^{-1}$ dan puncak yang tajam pada $3641 \mathrm{~cm}^{-1}$ [6]. Puncak penyerapan utama pada bilangan gelombang $1471,51 \mathrm{~cm}^{-1}$ dan puncak serapan minor pada bilangan gelombang $873,9 \mathrm{~cm}^{-1}$ menunjukkan adanya vibrasi peregangan asimetris [17]. Hasil ini menunjukkan bahwa $\mathrm{CaO}$ yang disintesis dari batu kapur belum memperoleh senyawa $\mathrm{CaO}$ murni karena $\mathrm{CaO}$ yang disintesis telah terkontaminasi $\mathrm{CO}_{2}$ dan $\mathrm{H}_{2} \mathrm{O}$ dari udara.
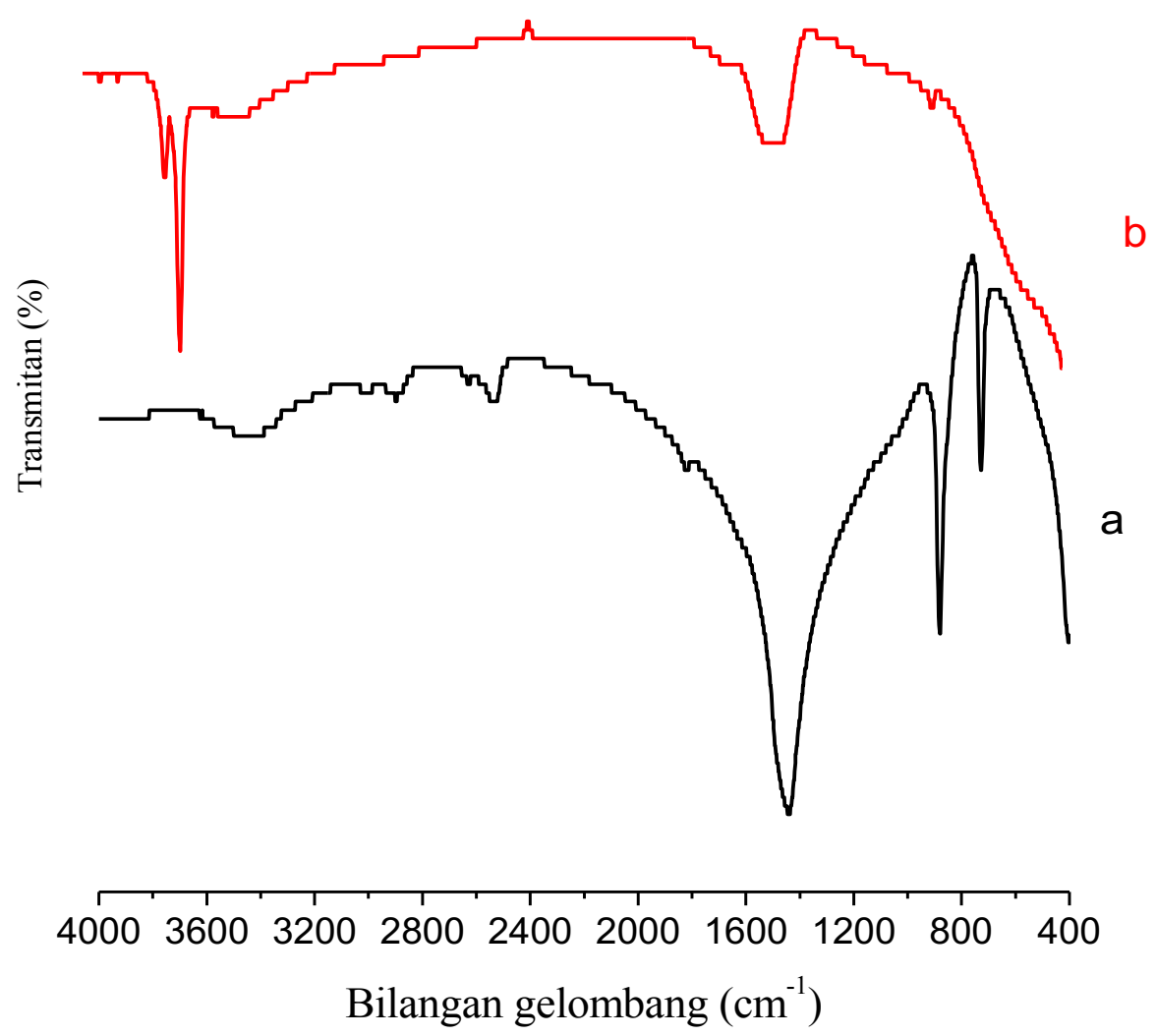

Gambar 4. Spektra FTIR dari sampel batu kapur sebelum kalsinasi (a) dan setelah kalsinasi (b)

$\mathrm{CaO}$ merupakan senyawa yang tidak stabil, mudah bereaksi dengan udara dan uap air membentuk $\mathrm{Ca}(\mathrm{OH})_{2}$ dan $\mathrm{CaCO}_{3}$ yang kemungkinan besar diperoleh selama preparasi sebelum $\mathrm{CaO}$ dianalisis dengan FTIR [6]. Hasil ini juga sesuai dengan karakterisasi menggunakan XRD yang menunjukkan bahwa $\mathrm{CaO}$ yang diperoleh mengandung fase $\mathrm{Ca}(\mathrm{OH})_{2}$. Oleh karena itu, kalsinasi sangat penting untuk mengubah batu kapur menjadi $\mathrm{CaO}$ [18]. 


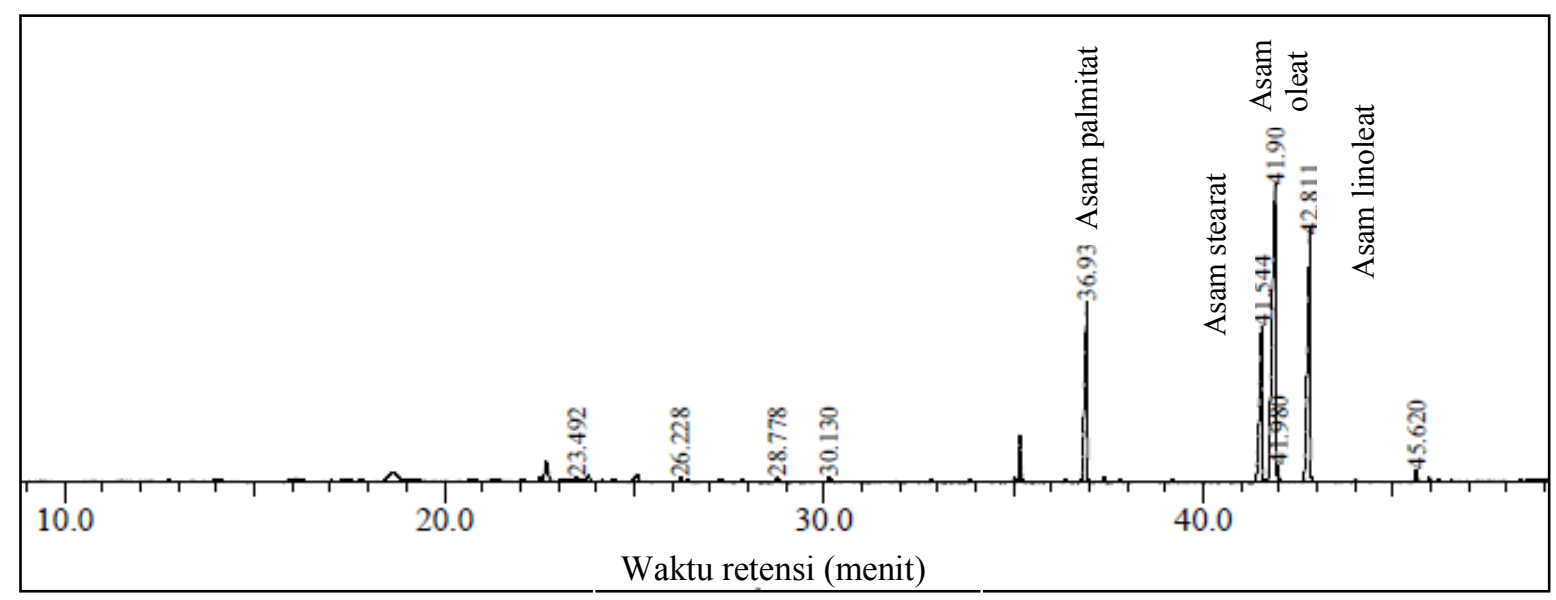

Gambar 5. Kromatogram dari sampel biodiesel

Kandungan minyak yang digunakan sebagai feedstock merupakan salah satu parameter penting yang mempengaruhi reaksi transesterifikasi, khususnya kandungan asam lemak bebas (FFA). Kadar FFA yang rendah sangat diperlukan untuk mendapatkan yield biodiesel yang tinggi pada reaksi transesterifikasi, karena kandungan FFA yang tinggi menyebabkan reaksi pembentukan sabun (reaksi saponifikasi) dan pada akhirnya akan menyebabkan penurunan konversi dan yield [19]. Reaksi penyabunan sangat tidak diharapkan terjadi dalam reaksi transesterifikasi karena selain mengurangi yield biodiesel juga menghambat pemisahan ester dari gliserol [20]. Oleh karena itu, untuk feedstock yang mempunyai kandungan FFA yang tinggi diperlukan preparasi terlebih dahulu. Kandungan FFA untuk minyak nyamplung pada penelitian ini diperoleh sebesar 5,3\%. Penurunan kadar FFA dapat dilakukan melalui reaksi esterifikasi. FFA dapat bereaksi dengan alkohol untuk membentuk ester (biodiesel) dengan katalis asam [19]. Oleh sebab itu perlu dilakukan preparasi minyak berupa reaksi esterifikasi sebelum dilakukan reaksi transesterifikasi. Hasilnya menunjukkan bahwa kandungan FFA pada minyak hasil reaksi esterifikasi sebesar 1,9 \%. Minyak hasil reaksi esterifikasi selanjutnya digunakan pada reaksi transesterifikasi. Pada transesterifikasi dengan metanol menggunakan katalis basa, proton dari metanol sebagai sisi utama membentuk anion metoksida pada tahap pertama reaksi. Anion metoksida menyerang karbon karbonil dari trigliserida, yang membentuk intermediet alkoksi karbonil. Kemudian, intermediet alkoksikarbonil terbagi menjadi 2 molekul yaitu metil ester dan anion digliserida [18]. Reaksi transesterifikasi tersebut ditunjukkan pada Gambar 6.

Pada penelitian ini reaksi transesterifikasi dilakukan dengan perbandingan mol metanol terhadap minyak sebesar 16:1. Katalis yang digunakan adalah katalis $\mathrm{CaO}$ yang berasal dari batu kapur Pamekasan, Madura, sebesar $4 \%(\mathrm{w} / \mathrm{w})$ dari berat minyak. Penggunaan katalis $\mathrm{CaO}$ yang mempunyai kadar kebasaan yang tinggi sangat berpengaruh terhadap yield biodiesel. Banyaknya katalis mempengaruhi sisi aktif $\mathrm{CaO}$ yang menghasilkan anion metoksida dari metanol. Sebagai molekul nukleofilik reaktif, anion metoksida menyerang karbon karbonil elektrofilik dalam trigliserida untuk menghasilkan biodiesel [21]. Kromatogram dari hasil analisis GC-MS ditunjukkan pada Gambar 5. Kromatogram tersebut menunjukkan bahwa sampel biodiesel terdiri dari asam palmitat, asam stearat, asam oleat dan asam linoleat. Berdasarkan perhitungan diperoleh nilai konversi sebesar $49 \%$ dan yield biodiesel sebesar 54\%. 
Tahap 1

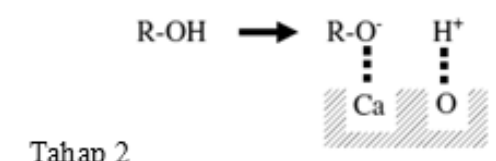

Tahap 2

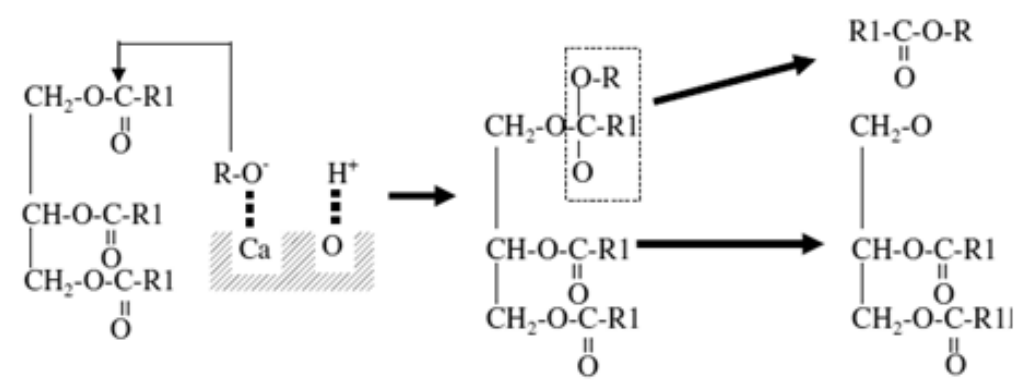

Tahap 3

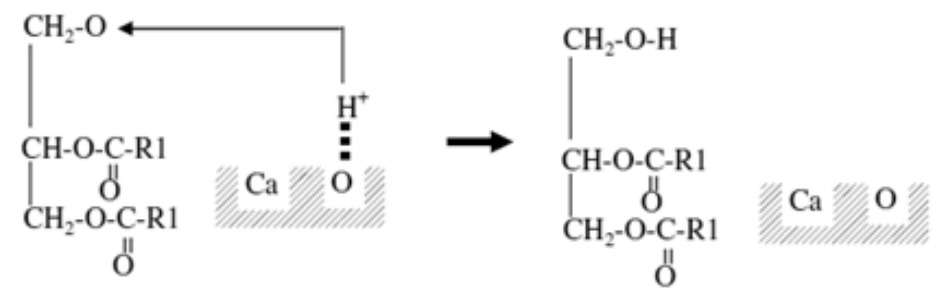

Gambar 6. Mekanisme reaksi dari transesterifikasi trigliserida dengan metanol menggunakan katalis $\mathrm{CaO}$

\section{KESIMPULAN}

Batu kapur dari Pamekasan, Madura dapat digunakan sebagai katalis heterogen dalam pembuatan biodiesel dari minyak nyamplung (Calophyllum inophyllum). Analisis XRD menunjukkan puncak karakteristik $\mathrm{CaO}$ dari sampel batu kapur pada $2 \theta=36,95^{\circ} ; 54,38^{\circ} ; 64,28^{\circ}$ dan $78,61^{\circ}$. CaO merupakan senyawa yang tidak stabil, mudah bereaksi dengan udara dan uap air membentuk $\mathrm{Ca}(\mathrm{OH})_{2}$ dan $\mathrm{CaCO}_{3}$ yang muncul pada spektrum FTIR. Analisis menggunakan SEMEDX menunjukkan katalis $\mathrm{CaO}$ dari batu kapur memiliki morfologi padatan menyerupai balok dan prisma serta diperoleh ukuran partikel sekitar $10 \mu \mathrm{m}$. Yield biodiesel sebesar 54\% diperoleh pada suhu reaksi $60^{\circ} \mathrm{C}$ selama 1 jam dengan rasio mol metanol terhadap minyak 1:16 dan katalis sebesar $4 \%(\mathrm{w} / \mathrm{w})$.

\section{Ucapan Terima Kasih}

Penulis mengucapkan terima kasih kepada Kementerian Pendidikan, Kebudayaan, Riset, dan Teknologi yang telah memberikan pendanaan penelitian Direktorat Riset dan Pengabdian Masyarakat (DRPM) skema Penelitian Dosen Pemula (PDP) Tahun 2020.

\section{Daftar Pustaka}

[1] S. uprapto, T. R. Fauziah, M. S. Sangi, T. P. Oetami, I. Qoniah, and D. Prasetyoko, "Calcium oxide from limestone as solid base catalyst in transesterification of Reutealis trisperma oil," Indones. J. Chem., vol. 16, no. 2, pp. 208-213, 2016.

[2] E. O. Ajala, M. A. Ajala, A. O. Ajao, H. B. Saka, and A. C. Oladipo, "Calcium-carbide Residue: A Precursor for the Synthesis of CaO-Al2O3-SiO2-CaSO4 Solid Acid Catalyst for Biodiesel Production using Waste Lard," Chem. Eng. J. Adv., p. 100033, 2020.

[3] A. M. Rabie, M. Shaban, M. R. Abukhadra, R. Hosny, S. A. Ahmed, and N. A. Negm, "Diatomite supported by $\mathrm{CaO} / \mathrm{MgO}$ nanocomposite as heterogeneous catalyst for biodiesel production from waste 
cooking oil," J. Mol. Liq., vol. 279, pp. 224-231, 2019.

[4] Hartati et al., "Highly selective hierarchical ZSM-5 from kaolin for catalytic cracking of Calophyllum inophyllum oil to biofuel," J. Energy Inst., 2020.

[5] I. Lawan, Z. N. Garba, W. Zhou, M. Zhang, and Z. Yuan, "Synergies between the microwave reactor and $\mathrm{CaO}$ /zeolite catalyst in waste lard biodiesel production," Renew. Energy, vol. 145, pp. 2550-2560, 2020.

[6] M. L. Granados et al., "Biodiesel from sunflower oil by using activated calcium oxide," Appl. Catal. B Environ., vol. 73, no. 3, pp. 317-326, 2007.

[7] T. F. Dossin, M. F. Reyniers, R. J. Berger, and G. B. Marin, "Simulation of heterogeneously MgOcatalyzed transesterification for fine-chemical and biodiesel industrial production," Appl. Catal. B Environ., vol. 67, no. 1-2, pp. 136-148, 2006.

[8] M. Zabeti, W. M. A. Wan Daud, and M. K. Aroua, "Activity of solid catalysts for biodiesel production: A review," Fuel Process. Technol., vol. 90, no. 6, pp. 770-777, 2009.

[9] P. R. Pandit and M. H. Fulekar, "Biodiesel production from microalgal biomass using $\mathrm{CaO}$ catalyst synthesized from natural waste material," Renew. Energy, vol. 136, pp. 837-845, 2019.

[10] K. N. Krishnamurthy, S. N. Sridhara, and C. S. Ananda Kumar, "Optimization and kinetic study of biodiesel production from Hydnocarpus wightiana oil and dairy waste scum using snail shell $\mathrm{CaO}$ nano catalyst," Renew. Energy, vol. 146, pp. 280-296, 2020.

[11] A. A. Ayodeji, M. E. Ojewumi, B. Rasheed, and J. M. Ayodele, "Data on $\mathrm{CaO}$ and eggshell catalysts used for biodiesel production," Data Br., vol. 19, pp. 1466-1473, 2018.

[12] K. Sudsakorn, S. Saiwuttikul, S. Palitsakun, A. Seubsai, and J. Limtrakul, "Biodiesel production from Jatropha Curcas oil using strontium-doped $\mathrm{CaO} / \mathrm{MgO}$ catalyst," J. Environ. Chem. Eng., vol. 5, no. 3, pp. 2845-2852, 2017.

[13] T. Maneerung, S. Kawi, and C. H. Wang, "Biomass gasification bottom ash as a source of $\mathrm{CaO}$ catalyst for biodiesel production via transesterification of palm oil," Energy Convers. Manag., vol. 92, pp. 234$243,2015$.

[14] A. Hamid, D. Prasetyoko, T. Esti, F. Rohmah, and I. Dayi, "Pengaruh Tahap Kristalisasi pada Sintesis ZSM-5 Mesopori dari Kaolin Alam,” vol. 03, no. 02, pp. 40-49, 2020.

[15] Rakhmad, N. Hindryawati, and Daniel, "Pembuatan Katalis Basa Heterogen Dari Batu Gamping ( Limestone )," Pros. Semin. Nas., pp. 101-105, 2017.

[16] N. Widiarti et al., "Upgrading catalytic activity of $\mathrm{NiO} / \mathrm{CaO} / \mathrm{MgO}$ from natural limestone as catalysts for transesterification of coconut oil to biodiesel," Biomass Convers. Biorefinery, 2021.

[17] T. Maneerung, S. Kawi, Y. Dai, and C. H. Wang, "Sustainable biodiesel production via transesterification of waste cooking oil by using $\mathrm{CaO}$ catalysts prepared from chicken manure," Energy Convers. Manag., vol. 123, pp. 487-497, 2016.

[18] M. Kouzu, T. Kasuno, M. Tajika, Y. Sugimoto, S. Yamanaka, and J. Hidaka, "Calcium oxide as a solid base catalyst for transesterification of soybean oil and its application to biodiesel production," Fuel, vol. 87, no. 12, pp. 2798-2806, 2008.

[19] N. U. Soriano, R. Venditti, and D. S. Argyropoulos, "Biodiesel synthesis via homogeneous Lewis acidcatalyzed transesterification," Fuel, vol. 88, no. 3, pp. 560-565, 2009.

[20] D. Y. C. Leung, X. Wu, and M. K. H. Leung, "A review on biodiesel production using catalyzed transesterification," Appl. Energy, vol. 87, no. 4, pp. 1083-1095, 2010.

[21] X. Liu, H. He, Y. Wang, S. Zhu, and X. Piao, "Transesterification of soybean oil to biodiesel using $\mathrm{CaO}$ as a solid base catalyst," Fuel, vol. 87, no. 2, pp. 216-221, 2008.

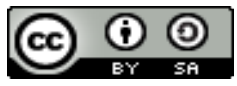

Jurnal IJCA is licensed under aÂ Creative Commons Attribution ShareAlike 4.0 